\title{
STUDY OF STRENGTH PROPERTIES OF CONCRETE BY USING MICRO SILICA AND NANO SILICA
}

\author{
S. Tanveer Hussain ${ }^{1}$, K.V.S.Gopala Krishna Sastry ${ }^{2}$ \\ ${ }^{1} M . T e c h$ student in civil engineering department, GPREC, Kurnool, AP, India \\ ${ }^{2}$ Associate Professor of civil engineering department, GPREC, Kurnool, AP, India
}

\begin{abstract}
Concrete is the most versatile material due to the persistent and continuous demands made on concrete, Engineers are continually pushing the limits to improve its performance with the help of innovative chemical admixtures and supplementary cementitious materials like fly ash, silica fume, granulated blast furnace slag and steel slag etc... The use of large quantity of cement produces increasing $\mathrm{CO}_{2}$ emissions and consequence the green house effect. A method to reduce the cement content in concrete mixes is the use of silica fume which is an amorphous (non-crystalline) polymorph of silicon dioxide, silica. It is an ultra fine powder collected as a byproduct of the silicon and ferrosilicon alloy production with an average particle diameter of 0.1 to $0.5 \mu$. The past investigations reveled that silica fume was an excellent pozzolanic material in producing High performance concrete (HPC).

Nano technology is one of the most promising areas of science. The use of nano materials in concrete is new revolution. Nano materials like nano silica, nano titanium oxide, carbon nano tubes, nano alumina etc... which are presently used in concrete to modify its strength properties. In the present study strength properties such as Compressive strength, split tensile strength and flexural strength of $M_{40}$ and $M_{50}$ grades of concrete with the use of micro silica $(5 \%, 7.5 \%, 10 \%, 15 \%)$ and nano silica $(1 \%, 1.5 \%$, $2 \%, 2.5 \%)$ as partial replacement of cement were studied. It was found from the experimental study that concrete composites with superior properties can be produced using micro silica, nano silica and combination of micro silica and nano silica.
\end{abstract}

Keywords: Colloidal Nano Silica (NS), Silica Fume (SF), Compressive strength (CS), Split tensile strength (ST) and Flexural strength (FS).

\section{INTRODUCTION}

Concrete is the most widely used construction material in the world. In recent years, researchers have focused on the improvement of concrete quality regarding its mechanical and durability properties. These can be achieved by the application of the supplementary cementitious materials.

Out of these supplementary cementitious materials, silica fume is the one of the waste materials that is being produced in tones of industrial waste per year in our country. The first testing of silica fume in Portland-cement-based concretes was carried out in 1952. The biggest drawback to exploring the properties of silica fume was a lack of material to experiment with. Early research used an expensive additive called fumed silica, an amorphous form of silica made by combustion of silicon tetrachloride in a hydrogen-oxygen flame. Silica fume on the other hand, is a very fine pozzolanic material. It is a byproduct of producing silicon metal or ferrosilicon alloys. One of the most beneficial uses of silica fume is in concrete. Because of its chemical and physical properties; it is a very reactive pozzolanic material. Concrete containing silica fume has very high strength and is very durable.

Recently Nano Technology has been introduced in Civil Engineering applications. One of the most used nano material is Nano Silica (NS). This is the first Nano product that has replaced the micro silica. The advancement made by the study of concrete at nano scale has proved that nano silica is much better than silica fume used in conventional concrete. Nano silica possess more pozzolanic nature, it has the capability to react with the free lime during the cement hydration and forms additional C-S-H gel which gives strength, impermeability and durability to concrete.

Verma ajay et al, (2012) ${ }^{[1]}$ have studied the effect of micro silica and the strength of concrete with ordinary Portland cement. They observed that silica fume increases the strength of concrete and reduces capillary pores. Dilip Kumar Singha Roy (2012) ${ }^{[2]}$ has investigated on the strength parameters of concrete made with partial replacement of cement by SF. T.Shanmugapriya (2013) ${ }^{[3]}$ studied the influence of silica fume on $\mathbf{M}_{60}$ concrete and found that $7.5 \%$ of silica fume replacement increases the maximum compressive strength, split tensile strength and flexural strength.

Ji (2005) ${ }^{[4]}$ studied the water permeability resistant behavior and micro structure of concrete with NS and observed that NS concrete has a better water resistant permeability than ordinary concrete. Ye Qing et al, (2007) ${ }^{[5]}$ studied the influence of silica fume and nano silica individually on fresh concrete and hardened concrete and found that consistency and setting times were different for NS and SF. NS makes cement paste thicker and accelerated the hydration process which improves the bond strength and compressive strength when compared with that of SF in concrete. Byung-Wan 
(2007) ${ }^{[6]}$ studied the properties of cement mortar with NS particles and reported the importance of addition of NS on mechanical properties. Lin et al. (2008) ${ }^{[7]}$ have observed the effect of NS addition on permeability and compressive strength of fly ash cement mortar. From the pore analysis study, it was reported that the relative permeability and pore sizes of concrete were decreased, whereas the compressive strength increased by adding more NS. Yazdi et al (2009) ${ }^{[8]}$ investigated the effect of NS on high volume fly ash concrete [HFC], and found that due to the low pozzolanic reactions of fly ash, early strength of HFC reduced considerably, but with the addition of NS promoted the pozzolanic activity reaction which enabled the enhancement of strength of HFC, especially in the early ages. Sadrmontazi Barzegar (2010) ${ }^{[9]}$ concluded that the properties of self compacting concrete with and without Rice Husk Ash [RHA], an agro-industry waste, and exhibited improvement in the physical and mechanical properties of concrete with addition of NS. A. Siva Sai, B.L.P. Swami, B.SaiKiran (2013) ${ }^{[10]}$ have observed the mechanical properties of $\mathrm{M}_{60}$ and $\mathrm{M}_{70}$ grade concrete with micro silica and in combination with colloidal nano-silica. They found that concrete composites with superior properties can be produced with the combination of microsilica and nano-silica. Mohammad Reza Zamani Abyaneh, et al (2013) ${ }^{[11]}$ have found that the concrete produced with $\mathrm{Micro}-\mathrm{SiO}_{2}$ and $\mathrm{Nano}-\mathrm{SiO}_{2}$ show higher degrees of quality in their compressive strength than the concrete which only have $\mathrm{Micro}-\mathrm{SiO}_{2}$ in their mixtures. Specimens with 2\% Nano- $\mathrm{SiO}_{2}$ and $10 \%$ Micro- $\mathrm{SiO}_{2}$ had less water absorption and more electrical resistance.

\section{MATERIALS USED AND THEIR}

\section{PROPERTIES}

In this present investigation materials used are Cement, Fine aggregate, Coarse aggregate, Silica Fume, Nano silica, Super plasticizer.

\subsection{Cement:}

Ultra tech cement of ordinary Portland cement (OPC) of 53 Grade was used which satisfies the requirements of IS: 12269-1987. The properties of cement are shown in Table 1.

Table 1 Properties of cement

\begin{tabular}{|l|l|l|}
\hline Sno & Property of cement & Results \\
\hline 1 & Normal Consistency & $31 \%$ \\
\hline 2 & Initial setting time & $120 \mathrm{~min}$ \\
\hline 3 & Final setting time & $250 \mathrm{~min}$ \\
\hline 4 & Specific gravity & 3.11 \\
\hline 5 & $\begin{array}{l}\text { Compressive strength of } \\
\text { cement at 28 days }\end{array}$ & $55.6 \quad \mathrm{mpa}$ \\
\hline
\end{tabular}

\subsection{Aggregate:}

Fine Aggregate: locally available sand collected from Tungabhadra River bed was used. The sand was conforming to zone II as per IS: 383-1987. The properties of fine aggregate are shown in Table 2.
Table 2 Properties of Fine aggregate

\begin{tabular}{|l|l|l|}
\hline Sno & Properties & Results \\
\hline 1 & Bulk density, $\mathrm{kg} / \mathrm{m}^{3}$ & 1650 \\
\hline 2 & Specific gravity & 2.68 \\
\hline 3 & Fineness modulus & 2.81 \\
\hline 4 & Free surface moisture $(\%)$ & 2.0 \\
\hline
\end{tabular}

Coarse Aggregate: The crushed aggregate was used from the local quarry. In this experiment the aggregate was used of 20mm down and tested as per IS: 2386-1963(I, II, III) specification. The properties of coarse aggregate are shown in Table 3.

Table 3 Properties of Coarse aggregate

\begin{tabular}{|l|l|l|}
\hline Sno & Property & Results \\
\hline 1 & Maximum nominal size & $20 \mathrm{~mm}$ \\
\hline 2 & Bulk density $\left(\mathrm{kg} / \mathrm{m}^{3}\right)$ & 1800 \\
\hline 3 & Specific gravity & 2.75 \\
\hline 4 & Fineness modulus & 4.6 \\
\hline
\end{tabular}

\subsection{Silica Fume:}

The silica fume was used in these experiments conforms to ASTM C 1240 and IS 15388:2003. The silica fume is extremely fine particle, which exists in white color powder form. Silica fume has been procured from Astrra chemicals Ltd-Chennai. The properties of silica fume is shown in Table 4

Table 4 Properties of silica fume.

\begin{tabular}{|l|l|l|}
\hline Sl. No. & Properties & Results \\
\hline 1 & Form & $\begin{array}{l}\text { Ultra fine amorphous } \\
\text { powder }\end{array}$ \\
\hline 2 & Colour & White \\
\hline 3 & Specific gravity & 2.63 \\
\hline 4 & Pack Density & $0.76 \mathrm{gm} / \mathrm{cc}$ \\
\hline 5 & Specific surface & $20 \mathrm{~m}^{2} / \mathrm{g}$ \\
\hline 6 & Particle size & $15 \mu \mathrm{m}$ \\
\hline 7 & Sio $_{2}$ & $99.89 \%$ \\
\hline
\end{tabular}

\subsection{Nano Silica:}

CemSyn ${ }^{\circledR}-X F X$ is a series of silica based binders /fillers obtained from Bee-chem: Chemicals Ltd., Kanpur. The properties of nano silica are shown in table-5

Table 5 Properties of nano silica

\begin{tabular}{|l|l|}
\hline State & Dispersed in water \\
\hline $\begin{array}{l}\text { Active nano Content } \\
(\% \mathrm{w} / \mathrm{w})\end{array}$ & $40.00-41.50$ \\
\hline Ph $\left(\mathbf{2 0}{ }^{\circ} \mathbf{C}\right)$ & $9.0-10.0$ \\
\hline Specific gravity & $1.30-1.32$ \\
\hline Particle size & $5-40 \mathrm{~nm}$ \\
\hline
\end{tabular}




\subsection{Super Plasticizers:}

Fosroc Aura mix 400 was used for $\mathrm{M}_{40}$ and $\mathrm{M}_{50}$ Grade of concrete. The properties of super plasticizer is shown in table6

Table 6 Properties of Aura mix 400 Super Plasticizer

\begin{tabular}{|c|c|}
\hline properties & \\
\hline Appearance & Light yellow coloured liquid \\
\hline $\mathrm{Ph}$ & Minimum 6.0 \\
\hline $\begin{array}{l}\text { Volumetric mass } \\
\text { @ } 20^{\circ} \mathrm{C}\end{array}$ & $1.09 \mathrm{~kg} /$ liter \\
\hline Chloride content & Nil \\
\hline Alkali content & $\begin{array}{l}\text { Typically less than } 1.5 \quad \mathrm{~g} \quad \mathrm{Na}_{2} \mathrm{O} \\
\text { equivalent liter of admixture }\end{array}$ \\
\hline
\end{tabular}

\section{EXPERIMENTAL PROGRAMME}

The experimental program was designed to compare the mechanical properties i.e. compressive strength, split tensile strength, and flexural strength of high strength concrete with $\mathbf{M}_{40}$ and $\mathbf{M}_{50}$ grade of concrete and with different replacement levels of ordinary Portland cement (ultra tech cement 53 grade) with silica fume $(5 \%, 7.5 \%, 10 \%$ and $15 \%)$ and nano silica $(1 \%, 1.5 \%, 2 \%$ and $2.5 \%)$. Strength properties of $\mathrm{M}_{40}$ and $\mathrm{M}_{50}$ grade concretes were also studied for combination of optimum replacement levels of SF $(7.5 \%)$ and NS (2\%).

\subsection{Mix Proportions:}

Two concrete mixes were designed to a compressive strength of $\mathrm{M}_{40}$ and $\mathrm{M}_{50}$ grades with water cement ratio of 0.36 and 0.33 respectively as per IS code 10262-2009. In the both cases, the cement was replaced with SF by $(5 \%$, $7.5 \%, 10 \%$ and $15 \%)$ and NS by $(1 \%, 1.5 \%, 2 \%$ and $2.5 \%)$ the proportions of constituent materials for two Mixes are presented in table 7

Table 7 Mix proportion of concrete

\begin{tabular}{|l|l|l|l|}
\hline SL. & \multirow{2}{*}{ Mo } & \multirow{2}{*}{ Materials } & \multicolumn{2}{|l|}{ Quantities in $\mathbf{K g} \mathbf{m}^{\mathbf{3}}$} \\
\cline { 3 - 4 } & & $\mathrm{M}_{40}$ Grade & $\mathbf{M}_{50}$ Grade \\
\hline 1 & Cement & 403 & 439.64 \\
\hline 2 & Water & 145.08 & 145.08 \\
\hline 3 & Fine aggregate & 682.670 & 659.969 \\
\hline 4 & Coarse aggregate & 1252.046 & 1242.802 \\
\hline 5 & Water cement ratio & 0.36 & 0.33 \\
\hline
\end{tabular}

The specimens of standard cubes (150mmx150mmx150mm), standard cylinders of $(150 \mathrm{~mm}$ Dia $\times 300 \mathrm{~mm}$ height) and standard beams of (100mmx100mmx500mm) were cast with various percentage replacements of SF and NS. Compression testing machine (CTM) was used to test 28 days compressive strength and split tensile strength of specimens. Universal Testing Machine (UTM) was used to test 28 days flexural strength of specimens

\section{RESULTS AND DISCUSSIONS}

\subsection{Mechanical Properties:}

\subsubsection{Compressive Strength:}

The compressive strength $\mathrm{M}_{40}$ and $\mathrm{M}_{50}$ grade concrete, SF concrete and NS concrete at the age of 28 days is presented in table 8 .

There is a significance improvement in the strength of concrete because of high pozzolanic nature of silica fume and nano silica and their filling ability. Compressive strength of two mixes $\mathrm{M}_{40}$ and $\mathrm{M}_{50}$ at 28 days age, with replacement of SF was increased gradually up to an optimum replacement level of $7.5 \%$ and then decreased. The maximum 28 days cube strength of $\mathrm{M}_{40}$ grade with $7.5 \%$ of silica fume was $61.24 \mathrm{~N} / \mathrm{mm}^{2}$ and of $\mathrm{M}_{50}$ grade with $7.5 \% \mathrm{SF}$ was $69.09 \mathrm{~N} / \mathrm{mm}^{2}$.

Compressive strength of $\mathrm{M}_{40}$ and $\mathrm{M}_{50}$ at 28 days age with replacement of NS was increased gradually up to an optimum replacement level of $2 \%$ and then decreased. The maximum 28 days cube compressive strength of $\mathrm{M}_{40}$ grade with $2 \% \mathrm{NS}$ was $59.61 \mathrm{~N} / \mathrm{mm}^{2}$ and of $\mathrm{M}_{50}$ grade with $2 \%$ NS was $69.72 \mathrm{~N} / \mathrm{mm}^{2}$.

The compressive strength of $\mathrm{M}_{40}$ grade concrete with partial replacement of cement by $7.5 \%$ SF shows $23.569 \%$ and of $\mathrm{M}_{50}$ grade with $7.5 \%$ replacement shows $22.534 \%$. The compressive strength of $\mathrm{M}_{40}$ grade concrete with partial replacement of cement by $2 \%$ NS shows $20.278 \%$ and of $\mathrm{M}_{50}$ grade with $2 \%$ replacement shows $22.236 \%$.

Compressive strength of $\mathrm{M}_{40} \& \mathrm{M}_{50}$ grades were also studied with the combination of SF at $7.5 \%$ and NS at $2 \%$ which results in a marginal improvement in strengths over respective optimal replacement levels of SF (7.5\%) and NS (2\%).Figure 1 and Figure 2 shows the variation of compressive strength of $\mathrm{M}_{40} \& \mathrm{M}_{50}$ grade with SF and NS replacements.

\subsubsection{Flexural Strength:}

The flexural strength of $\mathrm{M}_{40}$ and $\mathrm{M}_{50}$ grade concrete, SF concrete and NS concrete at the age of 28 days is presented in table 9 .

Flexural strength of two mixes $\mathrm{M}_{40}$ and $\mathrm{M}_{50}$ at 28 days age, with replacement of SF was increased gradually up to an optimum replacement level of $7.5 \%$ and then decreased. The maximum 28 days beam strength of $\mathrm{M}_{40}$ grade with $7.5 \%$ of silica fume was $4.160 \mathrm{~N} / \mathrm{mm}^{2}$ and of $\mathrm{M}_{50}$ grade with $7.5 \%$ SF was $4.560 \mathrm{~N} / \mathrm{mm}^{2}$

Flexural strength of $\mathrm{M}_{40}$ and $\mathrm{M}_{50}$ at 28 days age with replacement of NS was increased gradually up to an optimum replacement level of $2 \%$ and then decreased. The maximum 28 days beam flexural strength of $\mathbf{M}_{40}$ grade with $2 \% \mathrm{NS}$ was $4.45 \mathrm{~N} / \mathrm{mm}^{2}$ and of $\mathrm{M}_{50}$ grade with $2 \% \mathrm{NS}$ was $4.71 \mathrm{~N} / \mathrm{mm}^{2}$ 
The Flexural strength of $\mathrm{M}_{40}$ grade concrete with partial replacement of cement by $7.5 \%$ SF shows $9.186 \%$ and of $\mathrm{M}_{50}$ grade with $7.5 \%$ replacement shows $9.352 \%$. The Flexural strength of $\mathrm{M}_{40}$ grade concrete with partial replacement of cement by $2 \%$ NS shows $16.797 \%$ and of $\mathrm{M}_{50}$ grade with $2 \%$ replacement shows $13 \%$.

Flexural strength of $\mathrm{M}_{40} \& \mathrm{M}_{50}$ grades were also studied with the combination of SF at $7.5 \%$ and NS at $2 \%$ which results in a marginal improvement in strengths over respective optimal replacement levels of SF (7.5\%) and NS (2\%).Figure 3 and Figure 4 shows the variation of Flexural strength of $\mathrm{M}_{40} \& \mathrm{M}_{50}$ grade with $\mathrm{SF}$ and NS replacement results.

\subsubsection{Split Tensile Strength:}

The Split tensile strength $\mathrm{M}_{40}$ and $\mathrm{M}_{50}$ grade concrete, SF concrete and NS concrete at the age of 28 days is presented in table 10 .

Split tensile strength of two mixes $\mathrm{M}_{40}$ and $\mathrm{M}_{50}$ at 28 days age, with replacement of SF was increased gradually up to an optimum replacement level of $7.5 \%$ and then decreased. The maximum 28 days cylinder strength of $\mathrm{M}_{40}$ grade with $7.5 \%$ of silica fume was $3.960 \mathrm{~N} / \mathrm{mm}^{2}$ and of $\mathrm{M}_{50}$ grade with $7.5 \% \mathrm{SF}$ was $4.12 \mathrm{~N} / \mathrm{mm}^{2}$

Split tensile strength of $\mathrm{M}_{40}$ and $\mathrm{M}_{50}$ at 28 days age with replacement of NS was increased gradually up to an optimum replacement level of $2 \%$ and then decreased. The maximum 28 days cylinder Split tensile strength of $\mathbf{M}_{40}$ grade with $2 \% \mathrm{NS}$ was $4 \mathrm{~N} / \mathrm{mm}^{2}$ and of $\mathrm{M}_{50}$ grade with $2 \%$ NS was $4.320 \mathrm{~N} / \mathrm{mm}^{2}$

The Split tensile strength of $\mathrm{M}_{40}$ grade concrete with partial replacement of cement by $7.5 \%$ SF shows $21.472 \%$ and of $\mathrm{M}_{50}$ grade with $7.5 \%$ replacement shows $17.613 \%$. The Split tensile strength of $\mathbf{M}_{40}$ grade concrete with partial replacement of cement by $2 \%$ NS shows $22.7 \%$ and of $\mathrm{M}_{50}$ grade with $2 \%$ replacement shows $23.322 \%$.

Split tensile strength of $\mathrm{M}_{40} \& \mathrm{M}_{50}$ grades were also studied with the combination of SF at $7.5 \%$ and NS at $2 \%$ which results in a marginal improvement in strengths over respective optimal replacement levels of SF (7.5\%) and NS (2\%).Figure 5 and Figure 6 shows the variation of split tensile strength of $\mathrm{M}_{40} \& \mathrm{M}_{50}$ grade with $\mathrm{SF}$ and NS replacement results.

Table: 8 shows the compressive strength of concrete at 28 days

\begin{tabular}{|c|c|c|c|c|}
\hline \multirow{2}{*}{ SNO } & \multirow{2}{*}{$\begin{array}{l}\% \quad \text { Silica } \\
\text { Fume }\end{array}$} & \multirow{2}{*}{$\begin{array}{l}\% \quad \text { Nano } \\
\text { Silica }\end{array}$} & \multicolumn{2}{|c|}{$\begin{array}{l}\text { Compressive Strength } \\
\text { in } \mathrm{N} / \mathrm{mm}^{2}\end{array}$} \\
\hline & & & $\begin{array}{l}M_{40} \\
\text { Grade }\end{array}$ & $\begin{array}{l}\mathrm{M}_{50} \\
\text { Grade }\end{array}$ \\
\hline 1 & 0 & 0 & 49.56 & 57.037 \\
\hline 2 & 5 & 0 & 57.185 & 61.000 \\
\hline 3 & 7.5 & 0 & 61.241 & 69.890 \\
\hline 4 & 10 & 0 & 48.741 & 44.580 \\
\hline 5 & 15 & 0 & 46.222 & 42.074 \\
\hline
\end{tabular}

\begin{tabular}{|l|l|l|l|l|}
\hline 6 & 0 & 1 & 54.111 & 62.267 \\
\hline 7 & 0 & 1.5 & 55.250 & 65.790 \\
\hline 8 & 0 & 2 & 59.610 & 69.720 \\
\hline 9 & 0 & 2.5 & 47.000 & 51.415 \\
\hline 10 & 7.5 & 2 & 62.350 & 71.5 \\
\hline
\end{tabular}

Table: 9 shows the Flexural strength of concrete at 28 days

\begin{tabular}{|l|l|l|l|l|}
\hline \multirow{2}{*}{ SNO } & \multirow{2}{*}{$\begin{array}{l}\text { Fume } \\
\end{array}$} & Silica & \multirow{2}{*}{$\begin{array}{l}\text { Nano } \\
\text { Silica }\end{array}$} & $\begin{array}{l}\text { Flexural Strength in } \\
\mathbf{N} / \mathbf{m m}^{2}\end{array}$ \\
\cline { 4 - 5 } & & $\begin{array}{l}\mathbf{M}_{\mathbf{4 0}} \\
\text { Grade }\end{array}$ & $\begin{array}{l}\mathbf{M}_{\mathbf{5 0}} \\
\text { Grade }\end{array}$ \\
\hline 1 & 0 & 0 & 3.81 & 4.17 \\
\hline 2 & 5 & 0 & 4 & 4.280 \\
\hline 3 & 7.5 & 0 & 4.160 & 4.560 \\
\hline 4 & 10 & 0 & 3.760 & 3.985 \\
\hline 5 & 15 & 0 & 3.960 & 4.053 \\
\hline 6 & 0 & 1 & 4 & 4.250 \\
\hline 7 & 0 & 1.5 & 4.2 & 4.590 \\
\hline 8 & 0 & 2 & 4.450 & 4.710 \\
\hline 9 & 0 & 2.5 & 3.80 & 4 \\
\hline 10 & 7.5 & 2 & 4.53 & 4.840 \\
\hline
\end{tabular}

Table: 10 shows the split tensile strength of concrete at 28 days

\begin{tabular}{|l|l|l|l|l|}
\hline \multirow{2}{*}{ SNO } & \multirow{2}{*}{$\begin{array}{l}\text { Silica } \\
\text { Fume }\end{array}$} & $\begin{array}{l}\text { \% Nano } \\
\text { Silica }\end{array}$ & $\begin{array}{l}\text { Split } \\
\text { Strength in }\end{array}$ & \begin{tabular}{l} 
Tensile \\
\cline { 3 - 4 }
\end{tabular} \\
& & $\begin{array}{l}\mathbf{M}_{\mathbf{4 0}} \\
\text { Grade }\end{array}$ & $\begin{array}{l}\mathbf{M}_{\mathbf{5 0}} \\
\text { Grade }\end{array}$ \\
\hline 1 & 0 & 0 & 3.26 & 3.503 \\
\hline 2 & 5 & 0 & 3.840 & 4 \\
\hline 3 & 7.5 & 0 & 3.960 & 4.120 \\
\hline 4 & 10 & 0 & 3.010 & 3.210 \\
\hline 5 & 15 & 0 & 3.270 & 3.380 \\
\hline 6 & 0 & 1 & 3.748 & 3.981 \\
\hline 7 & 0 & 1.5 & 3.819 & 4 \\
\hline 8 & 0 & 2 & 4. & 4.320 \\
\hline 9 & 0 & 2.5 & 3.253 & 3.680 \\
\hline 10 & 7.5 & 2 & 4.1 & 4.380 \\
\hline
\end{tabular}

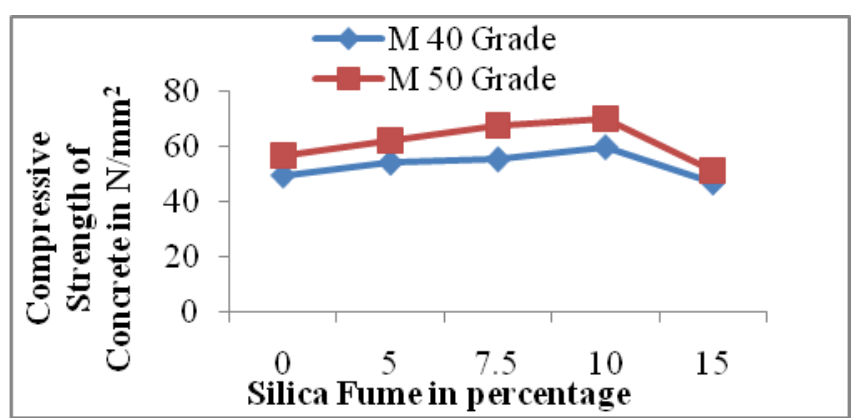

Fig: 1 Variation of compressive strength with silica fume 


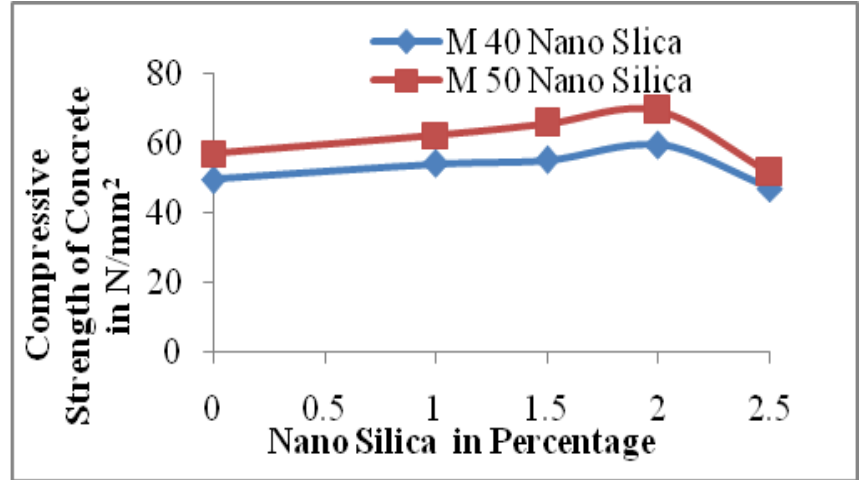

Fig: 2 Variation of compressive strength of concrete with nano silica

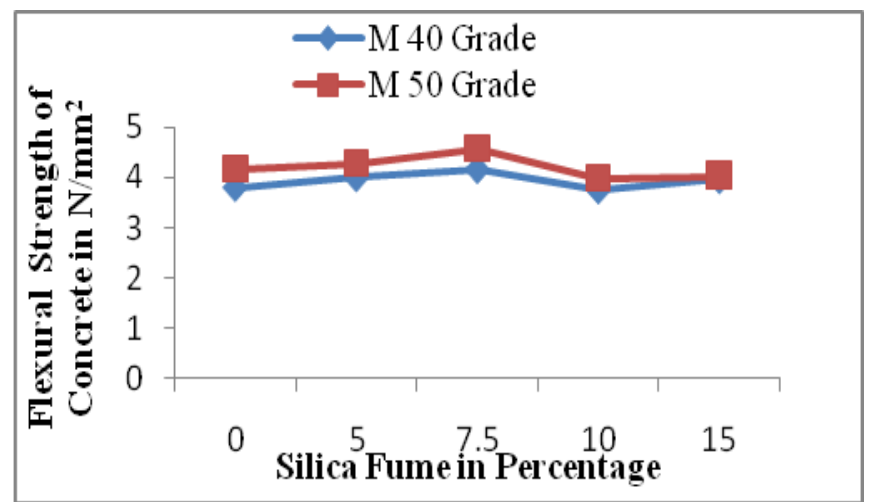

Fig: 3 Variation of flexural strength of concrete with silica fume

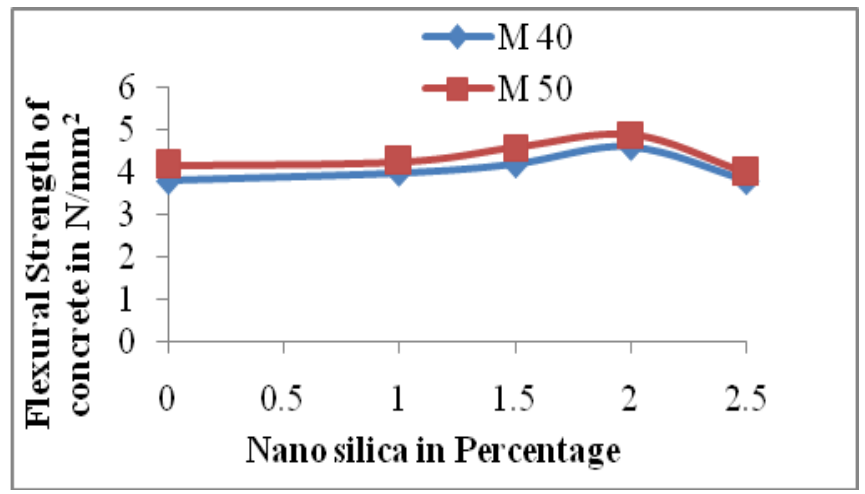

Fig: 4 Variation of Flexural strength of concrete with nano silica

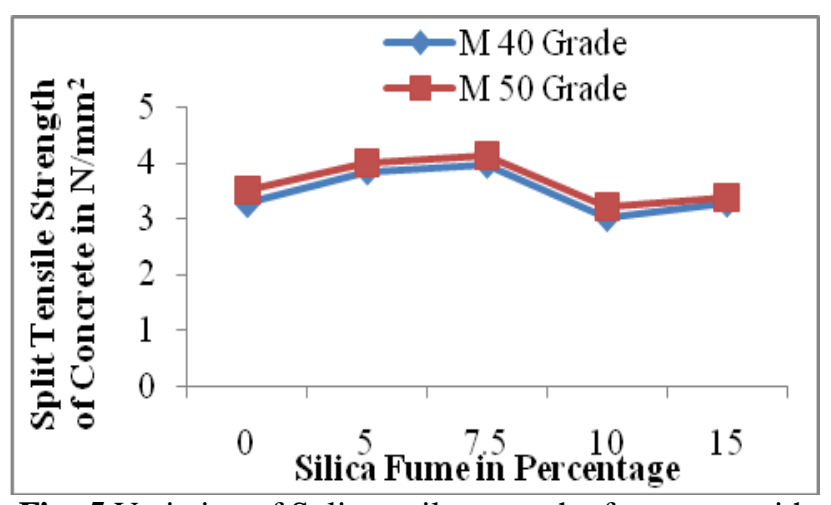

Fig: 5 Variation of Split tensile strength of concrete with silica fume

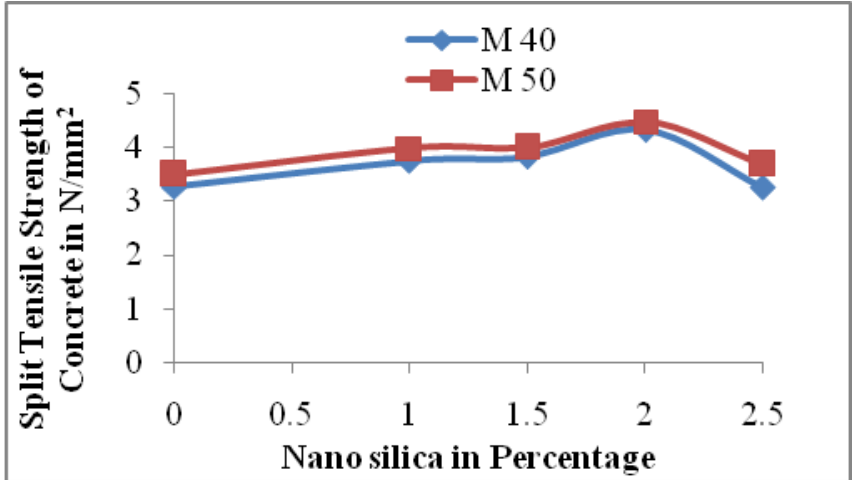

Fig: 6 variation of Split tensile strength of concrete with nano silica

\section{CONCLUSIONS}

Based on experimental results the following conlusions are drawn

1. Cement replacement up to $7.5 \%$ with SF and up to $2 \%$ with NS, leads to increasing compressive strength, split tensile strength and flexural strength for both $\mathrm{M}_{40}$ and $\mathrm{M}_{50}$ grade. Beyond $7.5 \%$ of SF and $2 \%$ of NS there is decreasing in compressive strength, split tensile strength and flexural strength for both $\mathrm{M}_{40}$ and $\mathrm{M}_{50}$ mixes.

2. The maximum replacement level of silica fume is $7.5 \%$ and nano silica is $2 \%$ for both $\mathrm{M}_{40}$ and $\mathrm{M}_{50}$ grade concrete.

3. The percentage increase in compressive strength, split tensile strength and flexural strength of concrete with combination of SF at $7.5 \%$ and NS at $2 \%$ is $(25.807 \%, 25.766 \%$ and $18.9 \%)$.for $\mathrm{M}_{40}$ grade and $(25.357 \%, 25.035 \%$ and $16.067 \%)$ for $\mathrm{M}_{50}$ grade concrete which is More when compared to normal concrete of $\mathrm{M}_{40}$ and $\mathrm{M}_{50}$ grades.

\section{REFERENCES}

[1] Verma Ajay, Chandak Rajeec and Yadav R.K. "Effect of micro silica on the strength of concrete with ordinary Portland cement" Reaserch journal of Engineering Science ISSN 2278-9472 vol.1(3), 1-4, sept (2012).

[2] Dilip Kumar Singha Roy "Effect of Partial Replacement of Cement by Silica Fume on Hardened Concrete". International journal of engineering Technology and Advanced Engineering (ISSN 2250-2459, volume 2, issue 8, August 2012)

[3] T. Shanmugapriya, Dr. R. N. Uma "Experimental Investigation on silica Fume as partial replacement of Cement in High Performance Concrete". (IJES) 2013

[4] Ji Tao, 2005. "Preliminary study on the water permeability and microstructure of concrete incorporating nano- $\mathrm{SiO}_{2}{ }^{\prime}$, Cement and Concrete Research, 35: 1943-1947.

[5] Ye Qing, Zenan Z., Deyu K. and Ch. Rongshen, "Influence of nano- $\mathrm{SiO}_{2}$ addition on properties of hardened cement paste as compared with silica fume”, Constr. Build Mater., 21, 539-545 (2007) 
[6] Jo Byung-Wan, Kim Chang-Hyun, Lim Jae-Hoon, "Characteristics of cement mortar with nano- $\mathrm{SiO}_{2}$ particles", ACI Mat. Jl., 104(4), 404-407 (2007).

[7] Lin D.F., Lin K.L., Chang W.C., Luo H.L and Cai M.Q., "Improvements of nano $\mathrm{SiO}_{2}$ on sludge/fly ash mortar", Waste Management, 28(6), 1081-1087 (2008).

[8] Yazdi A.D., Sohrabi M.R., Ghasemi M.R., Mohammad Danesh-Yazdi, "Investigation of NanoSiO2 Effects on High-Volume Fly Ash Concrete", 1st International Conference on Concrete Technology, Iran (2009).

[9] Sadrmomtazi A., Barzegar A., "Assessment of the effect of Nano-SiO2 on physical and mechanical properties of self-compacting concrete containing rice husk ash", Second Intl. Conf. on Sustainable Construction Materials and Technologies, June 2830, University Politecnica delle Marche, Ancona, Italy (2010).

[10] Mohammad Reza Zamani Abyaneh, Alireza Mehran, Seyed Mohammad Mahdi Hoseini, (2013) "Effects of Nano-Silica on Permeability of Concrete and Steel Bars Reinforcement Corrosion" Australian Journal of Basic and Applied Sciences, 7(2): 464467, 2013 ISSN 1991-8178.

[11] IS 456-2000, "Indian Standard Code of Practice for plain and reinforced concrete" Fourth revision, BIS, New Delhi.

[12] IS 383-1970, "Indian Standard Specification for coarse and fine aggregate from natural source for concrete," 2nd Edition, BIS, New Delhi.

[13] IS 2386-1963, "Indian Standard Methods of tests for aggregate" BIS, New Delhi.

[14] IS: 12269-1987, "Indian Standard Ordinary Portland Cement 53 grade Specification" BIS, New Delhi.

[15] IS: 10262-1982, "Recommended guidelines for concrete mix design, "BIS, New Delhi.

\section{BIOGRAPHIES}

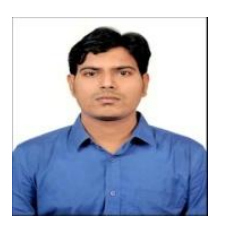

S.Tanveer Hussain, M.Tech Student in Civil Engineering Department, G.Pulla Reddy Engineering College, Kurnool, Andhra Pradesh.

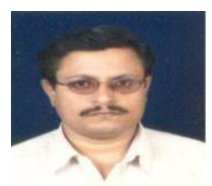

"K.V.S Gopala Krishna Sastry, Associate Professor, Department of Civil Engineering, G. Pulla Reddy Engineering College, Kurnool, Andhra Pradesh. The field of specialization is Structural Engineering. He has 24 years of academic experience at under graduate level including 2 years of post graduate level". 